\title{
Реперфузійне пошкодження тонкої кишки у хворих на гостру тонко- кишкову непрохідність
}

\author{
K. H. POLYATSKO \\ SHEI "Ternopil State Medical University by I. Ya. Horbachevsky"
}

\section{REPERFUSION INJURY OF THE SMALL INTESTINE IN PATIENTS WITH AN ACUTE INTESTINAL OBSTRUCTION}

\begin{abstract}
На основі дослідження рівня маркера пошкодження тонкої кишки I-FABP вивчено ішемічне та реперфузійне пошкодження тонкої кишки у хворих з гострою тонкокишковою непрохідністю. Встановлено, що тяжкість реперфузійного пошкодження тонкої кишки залежить від стадії непрохідності та тяжкості синдрому ентеральної недостатності. Виконання назоінтестинальної інтубації у хворих з гострою непрохідністю тонкої кишки в умовах декомпенсованої ентеральної недостатності призводить до поглиблення ішемічно-реперфузійних розладів. У даної категорії хворих перевагу слід віддавати виконанню одномоментної декомпресії привідної петлі.

The level marker of damage of the small intestine I-FABP, based on the research was studied the ischemic and reperfusion injury of small intestine in patients with an acute intestinal obstruction. It was established that the severity of reperfusion injury of the small intestine depends on the stage of obstruction and severity of the syndrome of enteral insufficiency. Performance intestynal intubation in patients with an acute small bowel obstruction in terms decompensated enteral insufficiency leads to ischemic-reperfusion deepening frustration. In these patients preference should be given to the implementation of one-stage loop drive decompression.
\end{abstract}

Постановка проблеми і аналіз останніх досліджень та публікацій. Розлади гемомікроциркуляції в кишковій стінці у патогенезі гострої непрохідності тонкого кишечника є основною ланкою, яка визначає тяжкість перебігу та прогноз захворювання [2]. Мікроциркуляторні розлади настають раніше клінічних проявів і зникають пізніше останніх [1]. Розлади мікроциркуляції у кишечнику до ліквідації непрохідності мають однотипний характер і залежать, перш за все, від ступеня та тривалості ішемії [3], а після ліквідації непрохідності визначають направленість морфологічних змін у кишщі та динаміку перебігу післяопераційного періоду [4], залишаючись основною причиною летальних випадків і ускладнень у вигляді постішемічних (реперфузійних) ускладнень $[3,4,6]$. Зважаючи на анатомічні особливості тонкої кишки (ТК) в плані доступності ї̈ стінки для морфологічних досліджень у клінічних умовах, залишаються невивченими ступінь вираження ї̈ реперфузійного пошкодження у хворих на гостру непрохідність тонкої кишки (ГНТК). У роботі Beuk R. J. та співавт., присвяченій ішемічно-реперфузійному пошкодженню ТК, серед методів дослідження в експерименті авторами використано специфічний мар- кер тканинного пошкодження слизової оболонки TK - Intestine fatty acids binding proteins (I-FABP) [7]. I-FABP - це внутрішньоклітинні протеїни з молекулярною масою близько 15 кДа, зв'язані жирними кислотами, яким властивий високий ступінь тканинної специфічності з виключною локалізацією в епітеліальних клітинах ТК.

Мета роботи: на основі визначення динаміки рівня I-FАВР вивчити особливості перебігу реперфузійного пошкодження тонкої кишки у хворих 3 ГНТК залежно від виду непрохідності, характеру операційного втручання.

Матеріали і методи. Ми вивчили концентрацію I-FABР у 32 пацієнтів (у 31 хворого на ГНТК середнім віком $(57,4 \pm 19,7)$ року та в 1 пацієнтки віком 73 роки з тотальним мезентеріальним тромбозом) та у 10 практично здорових осіб контрольної групи віком $(36,2 \pm 12,5)$ року. Значну більшість обстежених хворих на ГНТК склали жінки - 22-71 \%, чоловіків було, відповідно, 9-29 \%. У 17 хворих причиною ГНТК була спайкова хвороба, у 9 - защемлення в пахових, стегнових, післяопераційних вентральних та внутрішніх грижах, у 2 випадках - заворот, в 1 
- перекрут навколо спайки петлі ТК, у 2 пацієнтів діагностовано жовчнокам'яну ГНТК та в одного - лімфому ілеоцекального кута. Прооперовано 28 пацієнтів, у 3 явища ГНТК спайкового генезу вдалося розрішити консервативними методами. Поширений серозно-фібринозний перитоніт діагностовано в 4 пацієнтів: у 2 випадках у пацієнтів із заворотом петлі ТK, у пацієнтки віком 72 роки з защемленою правобічною стегнової грижею, флегмоною грижового мішка і в пацієнтки з тотальним артеріальним мезентеріальним тромбозом. У перших трьох пацієнтів, крім ліквідації причини непрохідності, виконано резекцію частини ТК. Операційне лікування тотального мезентеріального тромбозу обмежено експлоративною лапаротомією. У пацієнтки віком 76 років із защемленою правобічною стегновою грижею в зв'язку з нежиттєздатністю странгуляційної борозни виконано ії перитонізацію та накладання обхідного ентеро-ентероанастомозу “бік в бік” з одномоментною декомпресією привідної петлі ТК.

У 16 хворих виконано декомпресію ТК: у 9 - тривалу назоінтестинальну декомпресію та у 7 - інтраопераційну одномоментну декомпресію привідної петлі через ентеротомний доступ.
Концентрацію I-FАВР у сироватці крові вивчали до операції, одразу після ліквідації непрохідності ТК і на 1-шу, 3-тю, 5-ту, 7-му доби післяопераційного періоду.

Результати досліджень та їх обговорення. В осіб контрольної групи концентрація I-FABР у сироватці крові становила $(102,4 \pm 47,2)$ нг$^{\circ} \pi^{-1}$. На момент госпіталізації в стаціонар концентрація I-FABР виявилася вищою, ніж у контролі, у 31 із 32 обстежених хворих та в середньому перевищувала контрольну величину у 8,7 раза. За рівнем I-FABP на момент госпіталізації оцінювали ступінь ішемічного пошкодження ТК. Причому ступінь ішемічного пошкодження ТК на момент прийняття залежав від стадії непрохідності і тяжкості СЕН за Саєнком В. Ф. та співавт. [5]. У хворих на ГНТК та з клінічними проявами СЕН у стадії компенсації концентрація I-FABР перевищувала показник контрольної групи на 146 \%, проте статистично достовірно не відрізнялася від нього. Наростання тяжкості СЕН супроводжується різким зростанням рівня I-FABP: у пацієнтів із II стадією на 677 \%, 3 III стадією - на 998 \% зі статистично достовірною різницею цих показників з контролем та між всіма підгрупами хворих (табл. 1).

Таблиця 1. Концентрація I-FАВР у сироватці крові хворих на ГНТК на момент госпіталізації при різних

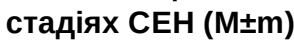

\begin{tabular}{||c|c|c|c|c||}
\hline \hline & \multirow{2}{*}{ Контроль } & \multicolumn{3}{|c||}{ Стадія СЕН } \\
\cline { 3 - 5 } & & $\mathrm{I}(\mathrm{n}=4)$ & $\mathrm{II}(\mathrm{n}=14)$ & $\mathrm{III}(\mathrm{n}=14)$ \\
\hline \multirow{2}{*}{$\mathrm{I}-\mathrm{FABP}, \mathrm{нг} \cdot \mathrm{J}^{-1}$} & \multirow{2}{*}{$102,4 \pm 47,2$} & $252,7 \pm 118,2$ & $795,9 \pm 162,0$ & $1125,0 \pm 311,3$ \\
& & $\mathrm{p}>0,05$ & $\mathrm{p}<0,001$ & $\mathrm{p}<0,001$ \\
\hline \hline
\end{tabular}

Примітка. р - статистична достовірність порівняно з контролем.

За ступенем підвищення концентрації I-FABP відразу після ліквідації непрохідності та на 1-шу, 3-тю, 5-ту, 7-му доби післяопераційного періоду оцінювали тяжкість та тривалість реперфузійного пошкодження ТК.

Консервативними методами вдалося розрішити явища ГНТКспайковогогенезу в Зпацієнтів із компенсованим та субкомпенсованим СЕН. Після ліквідації явищ ГНТК у даних пацієнтів реперфузійного пошкодження ТК не відмічали. Рівень I-FАВР у слизовій TK у пацієнтів із СЕН у стадії компенсації різко знижувався, що відмічено у зниженні концентрації
I-FABP до значень, які статистично достовірно не відрізнялися від контролю. У хворої з СЕН в стадії субкомпенсації концентрація I-FABP знизилася на 28,8 \% після початку лікування. Концентрацію I-FABP у сироватці крові хворих з ГНТК спайкового генезу, яку вдалося розрішити консервативно, наведено в таблиці 2. Тенденція до зниження рівня маркера пошкодження ТК до контрольної величини зберігалася протягом 3, 5, 7 діб після ліквідації явищ ГНТК $(\mathrm{p}>0,05)$.

Подібну динаміку зміни концентрації I-FABP у сироватці крові спостерігали у 2 пацієнтів із СЕН в

Таблиця 2. Концентрація I-FABP у сироватці крові хворих із ГНТК спайкового генезу, яку вдалося розрішити консервативно $(\mathrm{M} \pm \mathrm{m})$

\begin{tabular}{|c|c|c|c|c|}
\hline \multicolumn{5}{|c|}{ I-FABP, нг· $Л^{-1}$} \\
\hline \multirow{2}{*}{$\begin{array}{c}\text { до ліквідації явищ } \\
\text { ГНТК }\end{array}$} & \multicolumn{4}{|c|}{ після ліквідації явищ ГНТК } \\
\hline & 1-ша доба & 3-тя доба & 5-та доба & 7-ма доба \\
\hline $\begin{array}{c}533,2 \pm 336,2 \\
p>0,05\end{array}$ & $\begin{array}{c}179,7 \pm 62,5 \\
p>0,05\end{array}$ & $\begin{array}{c}147,0 \pm 37,4 \\
p>0,05\end{array}$ & $\begin{array}{c}114,0 \pm 54,9 \\
\mathrm{p}>0,05\end{array}$ & $\begin{array}{c}90,3 \pm 33,0 \\
\mathrm{p}>0,05\end{array}$ \\
\hline
\end{tabular}

Примітка. $\mathrm{p}_{1}$ - статистична достовірність порівняно з показником на момент госпіталізації. 
стадії компенсації після ліквідації защемленої грижі передньої черевної стінки.

У 10 пацієнтів СЕН у стадії субкомпенсації об’єм операційного втручання обмежувався ліквідацією непрохідності без декомпресії ТК. У 8 випадках життєздатність ТК не викликала сумніву-підгрупа А, а у 2 випадках мікроциркуляторні розлади ураженої петлі ТК перебували на межі декомпенсації-підгрупа В. Рівень I-FABР у хворих підгрупи А (табл. 3) після операції ліквідації причини непрохідності без проведення кишкової декомпресії збільшується на 3 \% - мінімальне реперфузійне пошкодження. В динаміці раннього післяопераційного періоду спостерігали поступове зниження концентрації I-FABP на 1-й день після операції лише на 18,6 \%, на 3-й день
- на 47,9 \%, на 5-й день - на 60,6 \%, на 7-й день - на 62,2 \% порівняно з показником до операції. У пацієнтів підгрупи В відмічали різке, більш ніж у 2,5 раза, зростання рівня I-FABР у сироватці крові на 1-й день після операції порівняно з показником на момент госпіталізації $(\mathrm{p}<0,05)$, що зумовлено масивним реперфузійним пошкодженням ТК. Протягом перших 5 діб після операції у підгрупі В відмічали високу активність некротичних процесів в ураженій петлі TK, про що свідчить стабільно висока концентрація I-FABP на рівні показника на висоті непрохідності. Лише на 7-му добу після операції рівень I-FABP зменшився лише до 49,8 \% від вихідної величини, проте статистично достовірно не відрізнявся від неї $(\mathrm{p}>0,05)$.

Таблиця 3. Концентрація I-FABP у сироватці крові хворих на ГНТК із субкомпенсованим CEH після

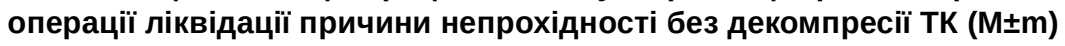

\begin{tabular}{|c|c|c|c|c|c|c|c|}
\hline & & & & I-FAB & $\Gamma \cdot \pi^{-1}$ & & \\
\hline & $\mathrm{n}$ & & & & сля операції & & \\
\hline & & до операци & відразу & 1-ша доба & 3-тя доба & 5-та доба & 7-ма доба \\
\hline Підгрупа А & 8 & $782,6 \pm 162,6$ & $\begin{array}{c}807,5 \pm 254,8 \\
p>0,05\end{array}$ & $\begin{array}{c}636,7 \pm 175,9 \\
p>0,05\end{array}$ & $\begin{array}{c}407,5 \pm 129,3 \\
p<0,001\end{array}$ & $\begin{array}{c}308,9 \pm 93,6 \\
p<0,001\end{array}$ & $\begin{array}{c}296,0 \pm 96,0 \\
p<0,001\end{array}$ \\
\hline Підгрупа В & 2 & $702,9 \pm 319,5$ & 2 ch & $\begin{array}{c}1761,1 \pm 182,6 \\
p<0,05\end{array}$ & $\begin{array}{c}891,7 \pm 91,0 \\
p>0,05\end{array}$ & $\begin{array}{c}687,6 \pm 117,9 \\
p>0,05\end{array}$ & $\begin{array}{c}349,7 \pm 61,1 \\
p>0,05\end{array}$ \\
\hline
\end{tabular}

Примітка. р - статистична достовірність порівняно з показником до операції.

Ліквідацію ГНТК з одномоментною інтраопераційною декомпресією привідної петлі ТК серед обстежених виконано у 7 пацієнтів із СЕН у стадії декомпенсації, у 4 з них виконано резекцію нежиттєздатної частини ТК. У пацієнтів, яким було виконано резекцію ТК та одномоментну ї̈ декомпресію, відмічено такі зміни концентрації I-FABP - зростання іï на 12,2 \% відразу після операції з наступним зниженням у 2,6 раза на 1-шу добу до рівня, меншого на 57,4 \%, ніж на момент госпіталізації, на 67,3 \% на 3-тю добу, на 75,0 \% - на 5-ту добу та на 84,3 \% - на 7-му добу після операції. При цьому статистично достовірне зниження рівня маркера пошкодження ТK порівняно з показником на момент госпіталізації було відмічено, починаючи з 1-ї доби після операції, а на 7-му добу після операції він статистично достовірно не відрізнявся від контрольної величини (табл. 4).
У пацієнтів з ГНТК, яким одномоментну декомпресію привідної петлі виконано через ентеротомний доступ у відвідній петлі без резекції ТК, концентрація I-FABP у сироватці крові на момент госпіталізації складала $(941,9 \pm 124,8)$ нг ${ }^{-1}$, що становило 79 \% від аналогічного показника у пацієнтів 3 нежиттєздатними змінами TK (p>0,05). Після операційного втручання рівень маркера пошкодження слизової оболонки ТК зріс на 15,3 \% - прояв реперфузійного пошкодження ураженої ТK. У подальшому відмічали зниження даного показника у 1,7 раза до рівня, меншого від показника на момент госпіталізації на 32,4, 54,2, 71,8 та 79,9 \%, відповідно, на 1-шу, 3-тю, 5-ту та 7-му добу після операції. Активність некротичних процесів слизової оболонки ТК за абсолютними показниками концентрації I-FABР на 5-ту та 7-му доби після операції була майже однаковою у пацієнтів із резекцією та без резекції ТК.

Таблиця 4. Концентрація I-FABP у сироватці крові хворих на ГНТК після операції ліквідації непрохідності з інтраопераційною одномоментною декомпресією привідної петлі ТK (M士m)

\begin{tabular}{|c|c|c|c|c|c|c|c|}
\hline & \multirow{3}{*}{$n$} & \multicolumn{6}{|c|}{ I-FABP, нг· $\pi^{-1}$} \\
\hline & & \multirow{2}{*}{ до операції } & \multicolumn{5}{|c|}{ після операції } \\
\hline & & & відразу & 1-ша доба & 3-тя доба & 5-та доба & 7-ма доба \\
\hline $\begin{array}{l}3 \text { резекцією } \\
\text { ТК }\end{array}$ & 4 & $1191,6 \pm 250,4$ & $\begin{array}{c}1336,6 \pm 181,8 \\
\mathrm{p}>0,05\end{array}$ & $\begin{array}{c}507,7 \pm 186,3 \\
\mathrm{p}<0,01\end{array}$ & $\begin{array}{c}390,2 \pm 172,3 \\
\mathrm{p}<0,01\end{array}$ & $\begin{array}{c}298,1 \pm 84,4 \\
\mathrm{p}<0,01\end{array}$ & $\begin{array}{c}187,6 \pm 79,6 \\
\mathrm{p}<0,01 \\
\end{array}$ \\
\hline $\begin{array}{l}\text { Без резекції } \\
\text { TK }\end{array}$ & 3 & $941,9 \pm 124,8$ & $\begin{array}{c}1086,4 \pm 139,5 \\
p>0,05\end{array}$ & $\begin{array}{c}636,6 \pm 282,9 \\
p>0,05\end{array}$ & $\begin{array}{c}431,1 \pm 191,5 \\
\mathrm{p}<0,05\end{array}$ & $\begin{array}{c}266,1 \pm 109,7 \\
\mathrm{p}<0,05\end{array}$ & $\begin{array}{c}189,4 \pm 20,9 \\
\mathrm{p}<0,05\end{array}$ \\
\hline
\end{tabular}

Примітка. p - статистична достовірність порівняно з показником до операції. 
Серед обстежених у 9 пацієнтів із ГНТК спайкового генезу проведено роз'єднання спайок, ліквідацію непрохідності та тривалу декомпресію ТК шляхом тотальної назоінтестинальної інтубації. Концентрація I-FABР відразу після операції зростала на 41,6 \%, що свідчить про досить високу травматичність даної маніпуляції. На 1-шу добу після операції відмічали зниження даного показника у 2,1 раза до величини на 53,4 \% меншої від рівня I-FABP до операції, а на 3-тю, 5-ту, 7-му доби, відповідно, на 70,8, 77,4 та 82,9 \%. У пацієнтів даної групи достовірне зниження рівня I-FABP порівняно з показником до операції відмічено, починаючи з 1-ї доби післяопераційного періоду, достовірне зниження до рівня у контрольній групі було відмічено на 7-му добу післяопераційного періоду спостереження (табл. 5).

Таблиця 5. Концентрація I-FABP у сироватці крові хворих на ГНТК після операції ліквідації спайкової

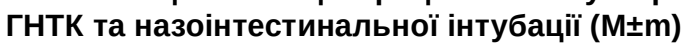

\begin{tabular}{||c|c|c|c|c|c||}
\hline \multirow{2}{*}{ До операції } & \multicolumn{5}{|c||}{ I-FАВР, нг· $\boldsymbol{\pi}^{-1}$} \\
\cline { 2 - 6 } & \multicolumn{5}{|c||}{ після операції } \\
\cline { 2 - 6 } & відразу & 1-ша доба & 3-тя доба & 5-та доба & доба \\
\hline $1026,9 \pm 343,1$ & $1453,1 \pm 450,0$ & $478,0 \pm 155,5$ & $300,8 \pm 104,4$ & $232,2 \pm 117,5$ & $175,8 \pm 69,2$ \\
& $\mathrm{p}<0,05$ & $\mathrm{p}<0,01$ & $\mathrm{p}<0,001$ & $\mathrm{p}<0,001$ & $\mathrm{p}<0,001$ \\
\hline
\end{tabular}

Примітка. р - статистична достовірність порівняно з показником до операції.

У пацієнтки з тотальним мезентеріальним тромбозом, яка госпіталізована через 16 год з моменту захворювання, концентрація I-FABР до операції становила 1479 нг॰ ${ }^{-1}$, на 1-шу добу після експлоративної лапаротомії - $1342 \mathrm{Hг}^{\circ} \pi^{-1}$.

Максимальну концентрацію I-FABP у сироватці крові - 2166 нг·л ${ }^{-1}$ відмічено відразу після операції ліквідації спайкової ГНТК та назоінтестинальної інтубації у пацієнтки СЕН в стадії декомпенсації. Мінімальна концентрація - 27,1 нг॰ ${ }^{1}{ }^{1}$ на 7-му добу після успішного консервативного лікування спайкової ГНТК у пацієнтки з СЕН у стадії компенсації.

На момент госпіталізації максимальна концентрація I-FABP - 1652 нг॰ ${ }^{-1}$ відмічена у пацієнтки зі спайковою ГНТК та СЕН у стадії декомпенсації, мінімальна - 120,4 нг॰ ${ }^{-1}$ у пацієнта зі спайковою ГНТК та СЕН у стадії компенсації, яка розрішилася під впливом консервативної терапії. На 7-му добу післяопераційного періоду максимальна концентрація I-FABP - 392,9 нг॰Л $\pi^{-1}$ відмічена у пацієнта 3 защемленою паховою грижею (тривалість захворю-

\section{СПИСОК ЛІТЕРАТУРИ}

1. Волобоев Н. А. Микроциркуляция при острых хирургических заболеваниях органов брюшной полости / Н. А. Волобоев // Хирургия. -1979. - № 10. - С. 72-78.

2. Ерюхин И. А. Кишечная непроходимость / И. А. Ерюхин,

В. П. Петров, М. Д. Ханевич. - СПб. : Питер, 1999. - 443 с.

3. Милюков В. Е. Изменения гемомикроциркуляторного русла при разных видах кишечной непроходимости / В. Е. Милюков // Морфология. - 2001. - № 5. - С. 31-34.

4. Пучков К. В. Патогенез нарушений и методы коррекции регионарной гемодинамики кишки при ее ишемии / К. В. Пучков, Б. Я. Гаусман, Д. В. Селиверстов // Хирургия. - 1997. - № 7. - С. 64-68. вання до моменту госпіталізації 4 доби), якому виконано герніотомію та герніопластику без резекції защемленої петлі ТK.

Висновки. 1. Визначення рівня маркера пошкодження тонкоїкишки I-FABРудинаміці-об’єктивний критерій оцінки тяжкості реперфузійного пошкодження тонкої кишки на різних етапах хірургічного лікування гострої непрохідності кишечника.

2. Реперфузійне пошкодження тонкої кишки після ліквідації тонкокишкової непрохідності відмічається у хворих із синдромом ентеральної недостатності в стадії субкомпенсації та декомпенсації.

3. Виконання назоінтестинальної інтубації у хворих із гострою непрохідністю тонкої кишки в умовах декомпенсованої ентеральної недостатності призводить до поглиблення ішемічно-реперфузійних розладів, про що свідчить зростання концентрації I-FABP відразу після операції на 41,6 \%. У даної категорії хворих перевагу слід віддавати виконанню одномоментної декомпресії привідної петлі.

5. Синдром ентеральної недостатності при гострій непрохідності кишечника і шляхи його корекції / В. Ф. Саєнко, І. І. Кобза, Ю. Б. Куцик А. С. Лаврик // Клін. хірургія. - 2001. - № 7. - C. 5-10.

6. Чернов В. Н. Выбор хирургической тактики и методов дезинтоксикации при острой непроходимости кишечника / В. Н. Чернов, Б. М. Велик // Хирургия. - 1999. - № 5. - С. 45-49.

7. Beuk R. Total warm ischemia and reperfusion impairs flow in all rat gut layers but increases leukocyte-vessel wall interactions in the submucosa only / R. Beuk, E. Heineman, G. Tangelder [et al.] // Ann. Surg. - 2000. - Vol. 231 . - P. 96-104. 